\title{
Different characteristics of char and soot in the atmosphere and their ratio as an indicator for source identification in Xi'an, China
}

\author{
Y. M. Han ${ }^{1,2}$, J.J. Cao ${ }^{1,3}$, S. C. Lee ${ }^{2,1}$, K. F. Ho ${ }^{2,1}$, and Z. S. An ${ }^{1}$ \\ ${ }^{1}$ SKLLQG, Institute of Earth Environment, Chinese Academy of Sciences, Xi' an 710075, China \\ ${ }^{2}$ Department of Civil and Structural Engineering, The Hong Kong Polytechnic University, Hung Hum, Kowloon, Hong Kong \\ ${ }^{3}$ Department of Environmental Sciences, Xi' an Jiaotong University, Xi' an, China
}

Received: 15 May 2009 - Published in Atmos. Chem. Phys. Discuss.: 16 June 2009

Revised: 13 December 2009 - Accepted: 11 January 2010 - Published: 22 January 2010

\begin{abstract}
Numerous definitions and analytical techniques for elemental (or black) carbon (EC) have been published in the scientific literature, but still no generally accepted interdisciplinary definition exists. EC is not a single chemical compound, but is mainly composed of two parts of carbon contents: combustion residues from pyrolysis and combustion emissions formed via gas-to-particle conversion. Accordingly EC is subdivided into two classes: char and soot. Char is defined as carbonaceous materials obtained by heating organic substances and formed directly from pyrolysis, or as an impure form of graphitic carbon obtained as a residue when carbonaceous material is partially burned or heated with limited access of air. Soot is defined as only those carbon particles that form at high temperature via gasphase processes. Since the different classes of EC have different chemical and physical properties, their optical lightabsorbing properties differ, so that it is essential to differentiate them in the environment. The thermal optical reflectance (TOR) method was used to differentiate between char-EC and soot-EC according to its stepwise thermal evolutional oxidation of different carbon fractions under different temperatures and atmosphere. Char-EC and soot-EC are operationally defined as EC1-OP and EC2+EC3 (EC1, EC2 and EC3 corresponding to carbon fractions evolved at 550, 700 and $800^{\circ} \mathrm{C}$ in a $98 \% \mathrm{He} / 2 \% \mathrm{O}_{2}$ atmosphere, respectively), respectively. One year of observations of the daily and seasonal variations of carbonaceous particles were conducted in Xi' an, China in 2004 to demonstrate the different characteristics of char and soot in the atmosphere. Total carbon (TC), organic carbon (OC), EC and char-EC showed
\end{abstract}

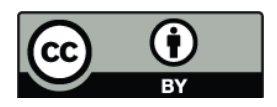

Correspondence to: Y. M. Han (yongming@ieecas.cn) similar seasonal trends, with high concentrations in winter and low concentrations in summer, while soot-EC revealed relatively small seasonal variations, with maximum concentration $\left(1.85 \pm 0.72 \mu \mathrm{g} \mathrm{m}^{-3}\right)$ in spring and minimum concentration $\left(1.15 \pm 0.47 \mu \mathrm{g} \mathrm{m}^{-3}\right)$ in summer. The strong correlation between EC and char-EC $\left(R^{2}=0.99\right)$ and poor correlation between $\mathrm{EC}$ and soot-EC $\left(R^{2}=0.31\right)$ indicate that previously reported total $\mathrm{EC}$ in the literature reflected the distribution characteristics of char only, while overlooking that of soot. However, soot exhibits stronger light-absorbing characteristics than char, and merits greater focus in climate research. The small seasonal variation of soot-EC indicates that soot may be the background fraction in total EC, and is likely to have an even longer lifetime in the atmosphere than previously estimated for total EC, which suggests that soot may has a greater contribution to global warming. While both char-EC/soot-EC and primary OC/EC ratios vary with emission sources, only $\mathrm{OC} / \mathrm{EC}$ ratio is affected by SOA. Thus char-EC/soot-EC may be a more effective indicator than OC/EC in source identification of carbonaceous aerosol. Comparison of seasonal variations of OC/EC and char-EC/soot-EC ratios in Xi'an confirms this point. However, wet scavenging by snow and rain was more effective for char than for soot and influenced the char-EC/soot-EC ratio, and this factor should be considered in source identification as well.

\section{Introduction}

Previous studies of carbonaceous aerosols have focused on two main classes: organic carbon (OC) and elemental carbon. EC is also termed black carbon (BC) and the two terms can be alternatively used based on the

Published by Copernicus Publications on behalf of the European Geosciences Union. 
different measurements of thermochemical and optical techniques (Pöschl, 2005). EC has received more attention in recent years because it contributes to global warming, carries carcinogenic compounds, and causes serious health risks (Jacobson, 2001; Menon et al., 2002; Avakian et al., 2002; Hansen and Nazarenko, 2004; Koelmans et al., 2006). It is estimated that the contributions by EC to global warming, in terms of direct climate forcing, is second only to $\mathrm{CO}_{2}$ (Jacobson, 2001), and reducing emissions of EC could mitigate the projected warming trends and delay the time of onset of the "dangerous" climate change (e.g. Shindell and Faluvegi, 2009). Globally, biomass and biofuel burning contributes about $62 \%$ to total EC and fossil fuel about 38\% (Bond et al, 2004).

The term EC was first introduced to atmospheric chemists by Novakov (1982) to describe "combustion derived black particulate carbon having a graphitic microstructure". Goldberg (1985) proposed two kinds of EC: "charcoals from biomass burning and soot from fossil fuel and wood combustion". Thereafter most of the scientists in soil and sediment fields followed the main idea of Goldberg's (1985). Kuhlbusch (1997) indicated that "EC is a constituent of combustion residues (charcoal) and combustion emissions (soot)". The different definitions for charcoal and soot were put forth as follows: "Charcoal is used for all black-colored material derived from solid or liquid organic matter that has had its chemical composition and ultrastructure significantly altered as a result of heating and retains the recognizable anatomic structure of the parent organic matter, even if only in fragmentary form". "Soot summarized all carbonaceous particles that are emitted by the combustion process and formed via gas-to-particle conversion”. Masiello (2004) proposed that "EC is a continuum of combustion products, ranging from slightly charred, degradable biomass to highly condensed, refractory soot", but the main idea was still similar to Goldberg's (1985), with the two parts of EC: combustion residues and emissions. Recently the term char is always used to replace the term charcoal in the literature (Elmquist et al., 2006; Han et al., 2007a).

In aerosol studies, the term char (or charcoal) is seldom used (it is replaced with the term EC) and EC is generally thought to be "the carbon content of the graphite-like material usually contained in soot (technically defined as the black product of incomplete hydrocarbon combustion or pyrolysis) and other combustion aerosol particles, which can be pictured as more or less disordered stacks of graphene layers or large polycyclic aromatics" (Pöschl, 2005). The careless use of the term EC and no differentiation between char (formed directly from the fuel by pyrolysis) and soot (formed via gas-to-particle conversion) often lead to confusion and sometimes infer wrong properties. For example, char measured in sediments and soils (Elmquist et al., 2006) was sometimes, or in part, proposed as brown carbon in aerosol studies (Gustafsson et al., 2009), which is suggested to be a kind of light-absorbing organic carbon (Andreae and
Gelencsér, 2006). In practice, the measurement of the two different carbon fractions, char and brown carbon, were often overlapped. However, as mentioned before, char was proposed as a kind of EC by Goldberg (1985) for decades, and this part of EC should be different from brown carbon. Most EC presently measured in aerosol studies also includes, at least, some of char (Hammes et al., 2007, Han et al., 2008). In this paper, the widely acknowledged terms, char and soot, in soil and sediment fields (Goldberg, 1985; Jones et al., 1997; Kuhlbusch, 1997; Masiello, 2004; Elmquist et al., 2006) were adopted in carbonaceous aerosol studies, and char is suggested as a kind of EC located between brown carbon (or colored organic carbon) and soot in the combustion continuum (Masiello, 2004; Pöschl, 2005). Char is defined as carbonaceous materials obtained by heating organic substances and formed directly from pyrolysis, or as an impure form of graphitic carbon obtained as a residue when carbonaceous material is partially burned or heated with limited access of air. The term soot is defined as only those carbon particles that form at high temperature via gas-phase processes by incomplete combustion.

Char and soot have different chemical and physical properties (Kuhlbusch, 1997; Masiello, 2004), as well as lightabsorbing properties (Bond, 2001; Bond et al., 2002; Kirchstetter et al., 2004; Reid et al., 2005). Char retains the morphology of the source material with diameters ranging mainly from 1 to $100 \mu \mathrm{m}$ (Masiello, 2004), and thus has no clear physical or chemical cut-off from the other end member of carbonaceous compounds, kerogen and humic-like materials (Lim and Cachier, 1996). Soot has a distinctive physical morphology (Goldberg, 1985) and is composed of submicron particles of grape-like clusters. Although char is also light-absorbing (Bond et al., 2002; Andreae and Gelencsér, 2006), its light-absorption property is weak and has a strong spectral dependence, tending to absorb strongly in the UV spectrum (Bond, 2001; Bond et al., 2002; Kirchstetter et al., 2004, Lewis et al., 2008). Soot exhibits strong light absorption characteristics with little spectral dependence (Schnaiter et al., 2003; Kirchstetter et al., 2004). The differentiation between char and soot in the environment would help us better understand their environmental and climatic impacts.

To date, there is no universally accepted method for EC determination. Artifacts exist in different EC methods (Hammes et al., 2007), including the thermal optical (TO) method, which was suggested to be the most reliable method for aerosol OC/EC determination (Gelencsér, 2004). In this method, OC evolves in the inert atmosphere, and pyrolyzed organic carbon (POC) would be produced. The POC determination depends on the two assumptions (Yang and $\mathrm{Yu}$, 2002): (1) POC and native EC have the same light attenuation coefficient, and (2) POC evolves before the native $\mathrm{EC}$ in the oxidizing atmosphere. These assumptions may be somewhat arbitrary and thus would result in artifacts (Cheng et al., 2009). For example, the difference of POC and native EC in the light attenuation coefficient has been proved by Chow 
et al. (2004b) and Subramanian et al. (2006). In addition, some catalysts and ions in samples may decrease the activation energy of $\mathrm{EC}$ in the analysis process, leading to negative results (underestimation) (Novakov and Corrigan, 1995; Han et al., 2009a). In coal combustion aerosols, it is also possible that abundant cations such as sodium or potassium may cause premature evolution of soot carbon and yield a false char EC. Moreover, some water extract of urban or marine aerosols, as well as pure starch or cellulose was not found to be evolved in OC oxidization steps (e.g. Yu et al., 2002; Schauer et al., 2003), resulting in positive results (overestimation). Biomass burning and coal combustion can give off a lot of large molecular weight water-soluble compounds, which may pyrolyze, and yield false char EC signal. The sampling artifact is another factor that complicates the measurement of carbonaceous aerosols. Adsorption of gaseous OC onto the quartz filter leads to overestimation of the particulate organic carbon (positive artifact), while volatilization of the collected particulate matter from the filter results in the underestimation of particulate organic carbon (negative artifact) (Turpin et al. 2000; Kirchstetter et al., 2001; Subramanian, 2004; Olson and Norris, 2005; Cheng et al., 2009). This may have an impact on the use of OC/EC ratio in source identification. Furthermore, the adsorption of gaseous $\mathrm{OC}$ is prone to charring in the process of OC/EC determination. However, the monitoring of charring may compensate for this part of OC although the different analysis temperature programs may result in different sensitivity of the OC/EC split (Schauer et al., 2003). Although the assumptions for POC determination are somewhat arbitrary, the monitoring of the charring of OC itself is still the key point in the TO method (Gelencsér, 2004).

Apart from the artifacts existing in the sampling and the EC determination processes, the most important factor that complicates EC determination in the environment may come from the uncertainty of the definition of the term EC since there is no clear physical characteristics for previous EC quantification. Comparison of EC between different methods showed that the discrepancy for the same sample using the different methods reaches up to more than 500 times (e.g. Schmidt et al., 2001; Hammes et al., 2007), which has been associated mainly with the different parts of EC measured with different methods. The TO method has two different protocols, IMPROVE (Interagency Monitoring of Protected Visual Environments) (Chow et al., 1993) and NIOSH (National Institute of Occupational Safety and Health) (Birch et al., 1998; NIOSH, 1999), for OC/EC determination. They present different EC definitions, which are called TOR (thermal optical reflectance) and TOT (thermal optical transmittance) EC for IMPROVE and NIOSH protocols, respectively. The two methods also give different EC results, and the TOR EC is generally higher than the TOT EC (Chow et al., 2001). This may result from the different parts measured by the two different methods as well (Hammes et al., 2007). Originally, the TOT method was designed for vehicle pollution, while the TOR method was designed for ambient environmental pollution (Chow et al., 2001). This may be the most important factor that impacts the split of OC/EC, as well as the POC determination. Thus, it is necessary to give the physical entities for the different parts of EC.

There have been few studies discriminating between char and soot. Recently, Han et al. (2007a) differentiate between char and soot using the TOR method, a commonly applied method for EC quantification (Chow et al., 1993). In the TOR method, carbon on filter substrates was made to evolve through programmed, progressive heating in a controlled atmosphere, making available eight separate carbon fractions - four OC, one POC and three EC. Han et al. (2007a) found that char and soot evolved in different conditions in the TOR method (char oxidized in $\mathrm{EC} 1$ conditions, at $550{ }^{\circ} \mathrm{C}$ in a $2 \%$ $\mathrm{O}_{2} / 98 \% \mathrm{He}$ atmosphere, and soot in EC2 and EC3 conditions, at $700{ }^{\circ} \mathrm{C}$ and $800^{\circ} \mathrm{C}$ in a $2 \% \mathrm{O}_{2} / 98 \%$ He atmosphere, respectively). Electron microscope analyses demonstrated that after EC1 was oxidized the majority of carbon remains are soot-like (Han et al., 2006). Also, comparing the TOR method with the chemothermal (CTO-375) method indicated that soot-EC determined by the CTO-375 method (Nguyen et al., 2004; Hammes et al., 2007) always corresponded to EC2 and EC3 determined by the TOR method (Han et al., 2007b). These suggest that the TOR method can be used to operationally differentiate between char and soot (Han et al., 2007). Just as the artifacts exist in the TOR method for EC determination, this is also the case for the quantification of char and soot. For example, the uncertainty for the POC determination also influences char-EC determination. Some catalysts and ions in the samples would affect the differentiation between char and soot (Novakov and Corrigan, 1995; Han et al., 2009a), leading to the evolving of some soot parts in the step of char oxidation. No clear-cut line between char and some organic matter would complicate the char determination.

EC forms from all combustion processes with three main sources: biomass burning, coal combustion, and motor vehicle exhaust. It has been suggested that primary emissions have distinct $\mathrm{OC} / \mathrm{EC}$ ratios, with higher values from biomass burning and lower levels from fossil fuel combustion (e.g. Turpin and Huntzicker, 1991; Castro et al., 1999; Cao et al., 2003, 2005, 2007; Kirchstetter et al., 2003; Malm et al., 2004; Zhang et al., 2007). Similarly, char-EC/soot-EC ratios may also have distinct values from primary emissions (Han et al., 2008). Ambient OC/EC ratio is generally influenced by three factors: primary emission source, different OC and EC removal rates by deposition, and secondary organic aerosol (SOA) formation (Cachier et al., 1996; Cao et al., 2005). However char-EC/soot-EC ratio is controlled predominately by combustion process, and is determined only by the first two factors. Since SOA accounts for a substantial fraction of carbon in aerosol (Turpin and Huntzicker, 1991; Castro et al., 1999; Cao et al., 2003; Schichtel et al., 2008) and it is not easy to obtain the exact percentage (Turpin and 

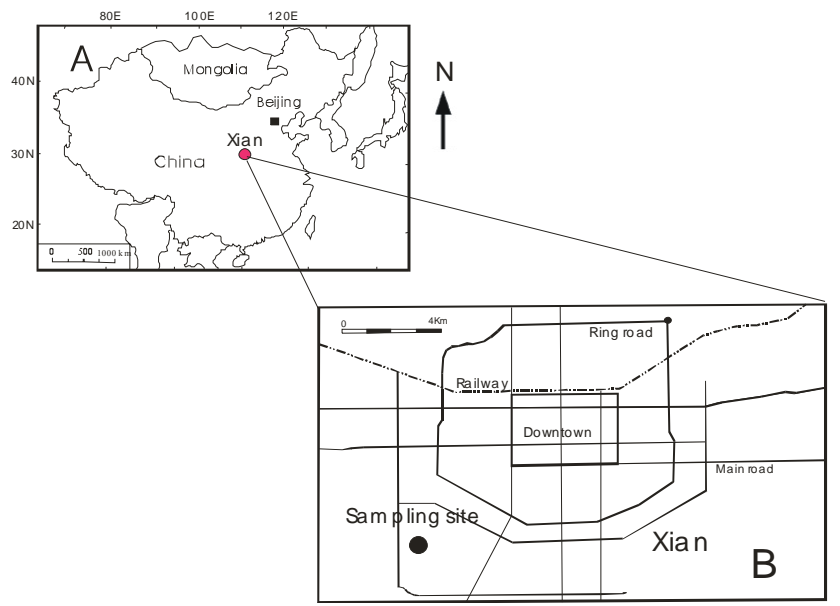

Fig. 1. Sampling site at Xi'an, Central China.

Huntzicker, 1991; Castro et al., 1999), substantial bias may exist in source identification using the OC/EC ratio. This problem does not exist for the char-EC/soot-EC ratio, and thus it may be better to use the char-EC/soot-EC ratio for source identification.

In order to demonstrate the different characteristics of char and soot, one year of observations of the daily and seasonal variations of carbonaceous particles, including total carbon (TC), OC, EC, char-EC, and soot-EC in $\mathrm{PM}_{2.5}$ (particulate matter with an aerodynamic diameter smaller than $2.5 \mathrm{mi}-$ crometers $[\mu \mathrm{m}])$ in Xi' an, China in 2004 are examined. In addition, the ratio of char to soot is tested as means of source identification for carbonaceous aerosols. The influence of wet scavenging on the behavior of char and soot and their ratios is also discussed.

\section{Sampling and analysis}

\subsection{Research area and sampling}

$\mathrm{Xi}$ 'an is the capital city of Shaanxi province in Central China, located on the Guanzhong Plain at $33^{\circ} 29^{\prime}-$ $34^{\circ} 44^{\prime} \mathrm{N}, 107^{\circ} 40^{\prime}-109^{\circ} 49^{\prime} \mathrm{E}$ (Fig. 1). The city is situated in a semi-arid zone, with an annual mean temperature of $13.0-13.4{ }^{\circ} \mathrm{C}$ and annual rainfall of $558-750 \mathrm{~mm}$ from 1950 to date (http://www.xawb.com/gb/city/2006-02/ 17/content_661171.htm). Rainfall generally occurs during July and September due to the East Asian monsoon system.

Sampling was carried out on the rooftop of the building of the Institute of Earth Environment, Chinese Academy of Sciences, at $10 \mathrm{~m}$ above ground, which is surrounded by a residential area $\sim 15 \mathrm{~km}$ south of downtown (Fig. 1) and has no major industrial activities. Daily $\mathrm{PM}_{2.5}$ samples were collected from January 1 to December 31 using mini-volume samplers (Airmetrics, Oregon, USA) operating at flow rates of $5 \mathrm{~L} \mathrm{~min}^{-1}$. Filter blanks were collected every month. All samples were acquired on pre-fired $\left(900^{\circ} \mathrm{C}\right.$ for three hours), pre-weighed $47 \mathrm{~mm}$ Whatman quartz-fiber filters for $24 \mathrm{~h}$ from 10:00 a.m. to 10:00 a.m. every day.

Meteorological data were monitored simultaneously with a HFY-IA Wind Speed/Wind Direction Instrument (Changchun Institute of Metrological Instruments, Changchun, Jilin Province, China). Meanwhile, daily temperatures and weather conditions such as rain, snow, dust storms, and visibility issued by the Xi' an Meteorological Bureau were manually recorded. Based on local meteorological characteristics, the four seasons were designated as January, February and December for winter, March to May for spring, June to August for summer, and September to November for fall.

\subsection{Carbon analysis}

Each filter was weighed twice before and after sampling using an electronic microbalance with $1 \mu \mathrm{g}$ sensitivity (MC5; Sartorius, Göttingen, Germany) in a controlled temperature and relative humidity environment $(35-45 \% \mathrm{RH}$ at 20 $23^{\circ} \mathrm{C}$ ). The filters were equilibrated for $24 \mathrm{~h}$ before gravimetric analysis. The precision of mass measurements before and after sampling based on replicate weighing were lower than $15 \mu \mathrm{g}$ per filter; filters were re-weighed if the difference between the replicate weighing was out of that range.

Carbon analyses were conducted with a Desert Research Institute (DRI) Model 2001 Carbon Analyzer (Atmoslytic Inc., Calabasas, CA) following the IMPROVE TOR protocol (Chow et al., 1993; Han et al., 2007a, b). A $0.526 \mathrm{~cm}^{2}$ punch from a quartz filter was heated to produce four OC fractions: $\mathrm{OC} 1, \mathrm{OC} 2, \mathrm{OC} 3$, and $\mathrm{OC} 4$ at temperatures of 120 , 250,450 , and $550^{\circ} \mathrm{C}$, respectively, in a non-oxidizing He atmosphere, and three EC fractions: EC1, EC2, EC3 at 550, 700 , and $800^{\circ} \mathrm{C}$, respectively, in an oxidizing atmosphere of $2 \% \mathrm{O}_{2} / 98 \% \mathrm{He}$. At the same time, $\mathrm{POC}$ was produced in the inert atmosphere, which decreases reflected light. When $\mathrm{O}_{2}$ was added the POC was oxidized and reflected light again increased. The POC was determined when a reflected laser light attained its original value after $\mathrm{O}_{2}$ was added. IMPROVE OC is defined as the sum of the four OC fractions plus $\mathrm{POC}$, and $\mathrm{EC}$ as the sum of the three $\mathrm{EC}$ fractions minus POC. The sum of OC and EC is total carbon (TC). According to Han et al. (2007a), char-EC is defined as EC1 minus POC, and soot-EC as the sum of EC2 and EC3. This differentiation has been used in both aerosol (Han et al., 2008) and sediment studies (Han et al., 2009a), as well as in soils and urban dusts to indicate local air pollution problems in China (Han et al., 2009b).

The analyzer was calibrated with known quantities of $\mathrm{CH}_{4}$ every day. Average concentrations of filter blanks were $1.56 \pm 1.01,0.42 \pm 0.28,0.32 \pm 0.24$, and $0.10 \pm 0.04 \mu \mathrm{g} \mathrm{m}^{-3}$ for OC, EC, char-EC, and soot-EC, respectively, which were subtracted from the ambient measurements. Replicate analyses were performed at the rate of one per group of 10 


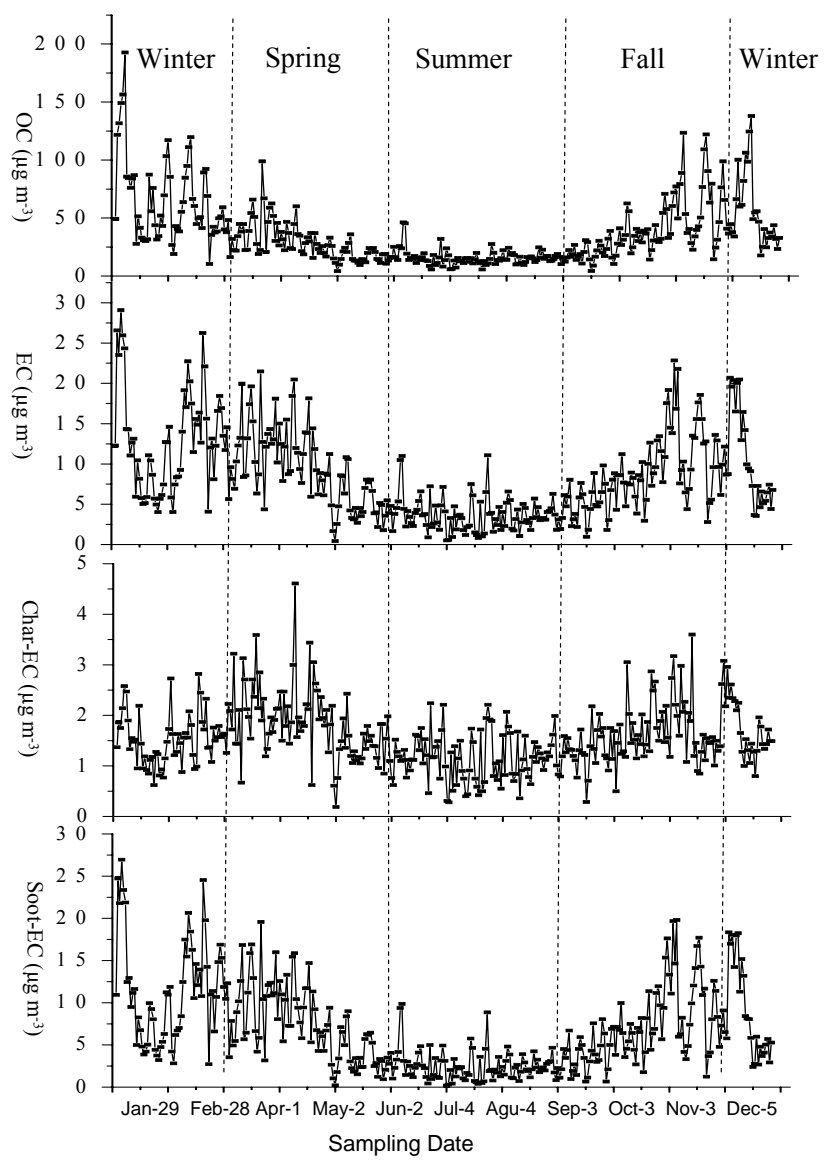

Fig. 2. Daily variations of organic carbon (OC), elemental carbon (EC), char-EC, and soot-EC concentrations in Xi' an in 2004.

samples. Comparison with average values from replicate analyses showed errors were $<5 \%$ for TC, $<8 \%$ for OC and $\mathrm{EC}$, and $<10 \%$ for char-EC and soot-EC.

\section{Results}

Daily and monthly variations in OC, EC, char-EC, and soot$\mathrm{EC}$, as well as daily mass and $\mathrm{TC}$ variations in $\mathrm{Xi}$ 'an are shown in Figs. 2 and 3. Also, seasonal mass and carbon concentrations, as well as their corresponding standard deviations, are summarized in Table 1. The annual average $\mathrm{PM}_{2.5}$ mass concentration was $178.54 \pm 113.83 \mu \mathrm{g} \mathrm{m}^{-3}$ (average \pm standard deviation), which is much higher than the National Ambient Air Quality Guideline of the European Union $\left(25 \mu \mathrm{g} \mathrm{m}^{-3}\right)$, as well as the Air Quality Guideline and the Interim Target-3, -2 and -1 of the World Health Organization (WHO) of $10,15,25$ and $35 \mathrm{\mu g} \mathrm{m}^{-3}$, respectively, indicating a very serious potential health concern for local residents. Average $\mathrm{OC}$ and EC concentrations were $36.39 \pm 28.90$ and $8.41 \pm 5.61 \mathrm{~g} \mathrm{~m}^{-3}$, respectively, contributing to $20.4 \%$ and $4.7 \%$ of the total $\mathrm{PM}_{2.5}$ mass, respectively.
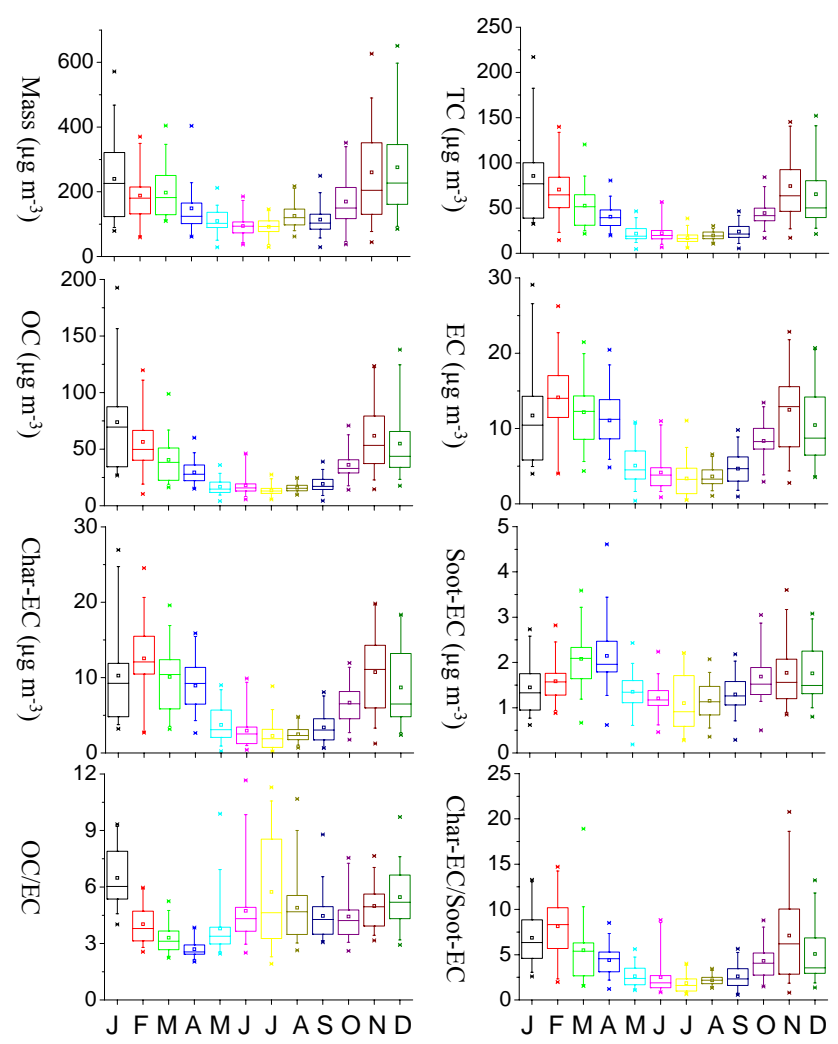

Fig. 3. Boxplots of monthly variations of mass, total carbon (TC), organic carbon (OC), elemental carbon (EC), char-EC, and sootEC concentrations, as well as OC/EC and char-EC/soot-EC ratios in Xi'an in 2004. The boxplot basically divides the variables into quartiles. The line inside the box represents the median; the small pane inside the box represents the average; the box marks the 25th and 75th percentiles; the horizontal line outside the box, as is also called whisker, marks the 5th and 95th percentiles; points outside the whisker are the maximum and minimum.

Comparing EC concentrations in $\mathrm{Xi}$ ' an with those of other Chinese cities reported in previous studies (e.g. He et al., 2001; Cao et al., 2003, 2007; Ye et al., 2003; Yu et al., 2004; Duan et al., 2007) indicates that EC is very high in $\mathrm{Xi}$ 'an, and this may also imply that char-EC is high since char-EC is well correlated with EC in different Chinese cities (Han et al., 2009d). This finding is consistent with a previous study on the spatial distribution of EC and char-EC from 14 Chinese cities (Cao et al., 2007; Han et al., 2009d). Average char-EC and soot-EC concentrations in $\mathrm{Xi}$ ' an were $6.86 \pm 5.28$ and $1.54 \pm 0.64 \mu \mathrm{g} \mathrm{m}^{-3}$, accounting for $81.6 \%$ and $18.4 \%$ of the total EC, respectively. The char-EC level was about 6 times higher than that in a small village in Daihai, Inner Mongolia (Han et al., 2008), which can be attributed to the difference in the amounts of fuel (coal) consumption between Xi'an, a mega-city, and Daihai, a rural mountain area. The soot-EC level was only about 2 times higher than that in Daihai $\left(0.69 \mu \mathrm{g} \mathrm{m}^{-3}\right)$, which may be associated with the fine size of soot particles that facilitates long range transport 
Table 1. Seasonal variations of mass, total carbon (TC), organic carbon (OC), elemental carbon (EC), OC/EC, char-EC, soot-EC, and char-EC/soot-EC.

\begin{tabular}{|c|c|c|c|c|c|c|c|c|c|}
\hline Seasons & Concentrations & $\begin{array}{l}\text { Mass } \\
\mu \mathrm{g} \mathrm{m}^{-3}\end{array}$ & $\begin{array}{l}\mathrm{TC} \\
\mu \mathrm{g} \mathrm{m}^{-3}\end{array}$ & $\begin{array}{l}\mathrm{OC} \\
\mu \mathrm{g} \mathrm{m}^{-3}\end{array}$ & $\begin{array}{l}\text { EC } \\
\mu \mathrm{g} \mathrm{m}^{-3}\end{array}$ & $\begin{array}{l}\mathrm{OC} / \\
\mathrm{EC}\end{array}$ & $\begin{array}{l}\text { Char-EC } \\
\mu \mathrm{g} \mathrm{m}^{-3}\end{array}$ & $\begin{array}{l}\text { Soot-EC } \\
\mu \mathrm{g} \mathrm{m}^{-3}\end{array}$ & $\begin{array}{l}\text { Char-EC/ } \\
\text { soot-EC }\end{array}$ \\
\hline \multirow{4}{*}{$\begin{array}{l}\text { Winter } \\
(n=90)\end{array}$} & Min & 59.20 & 14.52 & 10.45 & 3.56 & 2.56 & 2.39 & 0.62 & 1.37 \\
\hline & $\operatorname{Max}$ & 651.26 & 217.00 & 192.66 & 29.09 & 9.72 & 26.95 & 3.08 & 14.71 \\
\hline & Average & 235.41 & 74.05 & 61.96 & 12.08 & 5.35 & 10.49 & 1.60 & 6.69 \\
\hline & $\mathrm{SD}^{\mathrm{a}}$ & 125.14 & 40.01 & 34.94 & 6.22 & 1.71 & 5.95 & 0.54 & 3.31 \\
\hline \multirow{4}{*}{$\begin{array}{l}\text { Spring } \\
(n=87)\end{array}$} & Min & 28.40 & 4.66 & 4.18 & 0.42 & 2.04 & 0.19 & 0.23 & 1.08 \\
\hline & $\operatorname{Max}$ & 404.48 & 120.35 & 98.87 & 21.48 & 9.89 & 19.58 & 4.61 & 18.92 \\
\hline & Average & 152.14 & 38.04 & 28.67 & 9.37 & 3.27 & 7.52 & 1.85 & 4.14 \\
\hline & SD & 72.76 & 20.48 & 16.10 & 4.86 & 1.11 & 4.44 & 0.72 & 2.61 \\
\hline \multirow{4}{*}{$\begin{array}{l}\text { Summer } \\
(n=89)\end{array}$} & Min & 29.23 & 6.26 & 5.67 & 0.51 & 1.92 & 0.20 & 0.28 & 0.63 \\
\hline & Max & 217.30 & 56.68 & 46.20 & 11.07 & 11.67 & 9.88 & 2.24 & 8.82 \\
\hline & Average & 105.49 & 19.58 & 15.86 & 3.72 & 5.13 & 2.57 & 1.15 & 2.17 \\
\hline & $\mathrm{SD}$ & 38.34 & 8.41 & 6.71 & 2.13 & 2.31 & 1.82 & 0.47 & 1.30 \\
\hline \multirow{4}{*}{$\begin{array}{l}\text { Fall } \\
(n=88)\end{array}$} & Min & 28.94 & 5.43 & 4.47 & 0.97 & 2.61 & 0.66 & 0.29 & 0.57 \\
\hline & Max & 627.14 & 145.27 & 123.47 & 22.85 & 8.79 & 19.81 & 3.60 & 20.77 \\
\hline & Average & 179.70 & 47.05 & 38.62 & 8.43 & 4.62 & 6.85 & 1.58 & 4.62 \\
\hline & $\mathrm{SD}$ & 115.56 & 30.17 & 25.80 & 4.79 & 1.21 & 4.60 & 0.59 & 3.62 \\
\hline \multirow[t]{2}{*}{ Whole year } & Average & 178.54 & 44.79 & 36.39 & 8.41 & 4.61 & 6.86 & 1.54 & 4.41 \\
\hline & SD & 113.83 & 33.75 & 28.90 & 5.61 & 1.84 & 5.28 & 0.64 & 3.27 \\
\hline
\end{tabular}

a $\mathrm{SD}$ is standard deviation.

and thus leads to the relative small variation of soot concentrations between urban and rural areas. In contrast to the great differences of EC in different Chinese cities (Cao et al., 2007), the average soot-EC concentration in Xi' an was close to that from the 14 Chinese cities $\left(1.24 \pm 1.06 \mu \mathrm{g} \mathrm{m}^{-3}\right)$, which confirms the small variations in soot-EC values across China (Han et al., 2009d).

\section{Discussion}

\subsection{Variations in char-EC and soot-EC concentrations}

Concentrations of $\mathrm{PM}_{2.5}, \mathrm{TC}, \mathrm{OC}, \mathrm{EC}$, and char-EC showed similar patterns, with high concentrations in winter and low concentrations in summer. This pattern is similar to previous studies (e.g. Cao et al., 2003, 2005, 2007; Han et al., 2008) and is consistent with fuel consumption as winter heating generates heavy emissions in Xi' an (Han et al., 2009d). Soot-EC concentrations revealed a slightly different pattern, with the highest monthly concentrations in spring (March and April), but the lowest soot-EC level still occurred in summer. This trend is similar to that found in a previous study in a remote mountain area of Inner Mongolia in Northern China (Han et al., 2008), and is similar with CO variation with maximum concentration occurring during local spring in both northern and southern hemispheres (Yung et al., 1999). Both soot and CO can come from both fossil fuel combustion and biomass burning. In China, forest fires frequently occur in spring (March and April) after the long-term dry season in winter, which may contribute to the high soot-EC concentrations since forest fires may enhance the background level of soot concentrations in China. Comparison of daily, monthly and seasonal variations of char-EC and soot-EC concentrations (Fig. 3) indicated that abundance of char-EC was more variable. As suggested by Kuhlbusch (1997) and Masiello (2004), char and soot have different particle size, which is essential in determining transport distances. Since the particle size of char is much larger than that of soot, atmospheric char is easily deposited in situ and thus reflects the local combustion emissions. The maximum and minimum seasonal average char-EC concentrations were $10.49 \pm 5.95$ and $2.57 \pm 1.82 \mu \mathrm{g} \mathrm{m}{ }^{-3}$, respectively. Soot-EC showed a narrower seasonal variation, with a maximum level in spring $\left(1.85 \pm 0.72 \mu \mathrm{g} \mathrm{m}^{-3}\right)$ and minimum level in summer $\left(1.15 \pm 0.47 \mu \mathrm{g} \mathrm{m}^{-3}\right)$. This implies that soot may have an even longer lifetime than previously estimated for total EC (Orgen and Charlson, 1983) since soot is much smaller than total EC in size distribution.

\subsection{Correlations between different carbon particles}

Correlations between different carbonaceous materials are presented in Table 2. Similarly to many previous studies (e.g. Cao et al., 2003, 2005; Duan et al., 2007; Han et al., 2008), OC and EC in Xi' an were positively correlated $(p<0.0001)$, indicating common combustion sources for carbonaceous aerosols in urban areas. Char-EC showed stronger correlation with TC, OC, and EC than soot-EC, which may be a result of the different formation mechanism of char and 
Table 2. Correlations among total carbon (TC), organic carbon (OC), elemental carbon (EC), OC/EC, char-EC, soot-EC, and char-EC/sootEC, as well as high and low temperatures.

\begin{tabular}{|c|c|c|c|c|c|c|c|c|c|}
\hline & $\mathrm{TC}$ & $\mathrm{OC}$ & $\mathrm{EC}$ & $\mathrm{OC} / \mathrm{EC}$ & Char-EC & Soot-EC & $\begin{array}{r}\text { char-EC/ } \\
\text { soot-EC }\end{array}$ & Low Temp. & High Temp. \\
\hline $\mathrm{TC}$ & & 0.996 & 0.885 & 0.148 & 0.900 & 0.335 & 0.800 & -0.620 & -0.561 \\
\hline $\mathrm{OC}$ & 0.000 & & 0.839 & 0.217 & 0.858 & 0.282 & 0.782 & -0.615 & -0.567 \\
\hline $\mathrm{EC}$ & 0.000 & 0.000 & & -0.226 & 0.995 & 0.561 & 0.780 & -0.559 & -0.456 \\
\hline OC/EC & 0.005 & 0.000 & 0.000 & & -0.178 & -0.517 & 0.011 & -0.082 & -0.157 \\
\hline Char-EC & 0.000 & 0.000 & 0.000 & 0.001 & & 0.476 & 0.826 & -0.562 & -0.460 \\
\hline Soot-EC & 0.000 & 0.000 & 0.000 & 0.000 & 0.000 & & 0.025 & -0.269 & -0.208 \\
\hline char-EC/soot-EC & 0.000 & 0.000 & 0.000 & 0.844 & 0.000 & 0.645 & & -0.544 & -0.454 \\
\hline Low Temp. & 0.000 & 0.000 & 0.000 & 0.122 & 0.000 & 0.000 & 0.000 & & 0.952 \\
\hline High Temp. & 0.000 & 0.000 & 0.000 & 0.003 & 0.000 & 0.000 & 0.000 & 0.000 & \\
\hline
\end{tabular}

The right upper part is correlation coefficient; the left lower part is significant level.

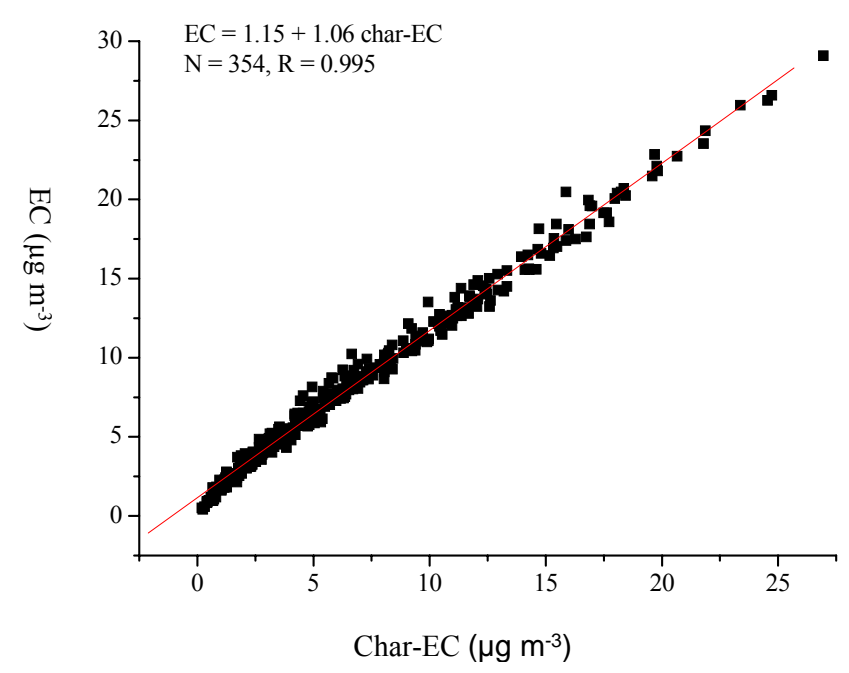

Fig. 4. Correlation between elemental carbon (EC) and char-EC.

soot (Han et al., 2009b), with char formed from combustion residues and soot from gas-particle condensation. EC had the strongest correlation with char-EC among these components, which is consistent with char-EC dominating the total EC. The regression equation between EC and char-EC (Fig. 4) is EC $=1.15+1.06^{*}$ char-EC $\left(R^{2}=0.99\right)$. The slope and intercept are similar to those obtained from the correlations between EC and char-EC from fourteen Chinese cities (Han et al., 2009d). This further confirms that previously reported EC concentrations measured with the TOR method can be used to calculate char-EC concentrations in urban areas. Since EC is the sum of char-EC and soot-EC, the intercept of $1.15 \mu \mathrm{g} \mathrm{m}^{-3}$ can be seen as the background value of soot-EC in Xi'an. This value is similar to the average concentration of soot-EC in summer. In the different seasons throughout the year, motor vehicle activities vary little, while coal heating is concentrated in winter, so the background of

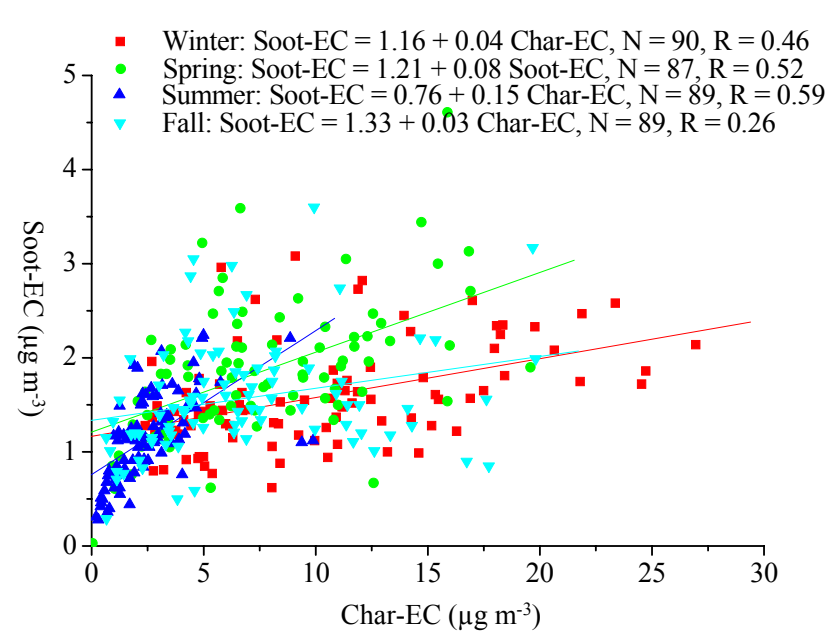

Fig. 5. Comparison of correlations between char-EC and soot-EC in different seasons in 2004.

soot may be derived mainly from vehicle exhaust. Previous researchers have referred to EC as a "proxy" for the concentration of soot carbon (see review by Andreae and Gelencsér, 2006). Our results suggest that previously reported EC may reflect char variations only.

EC and char-EC are moderately correlated with soot-EC in Xi'an, which may be affected by the background value of soot-EC. However, this relationship is stronger than that from fourteen Chinese cities (Han et al., 2009d), which showed poor correlation between char-EC and soot-EC. This result may be associated with the relatively limited range of sources for $\mathrm{EC}$ emissions in $\mathrm{Xi}$ ' an compared with those from the fourteen cities, which is shown by the narrow range of char-EC/soot-EC ratios from primary $\mathrm{Xi}$ ' an coal combustion emissions (1.5-3.0 from Cao et al. (2005) vs. 1.2-66.7 from Fig. 6). Comparison of the correlations between char-EC and soot-EC among the different four seasons (Fig. 5) showed 


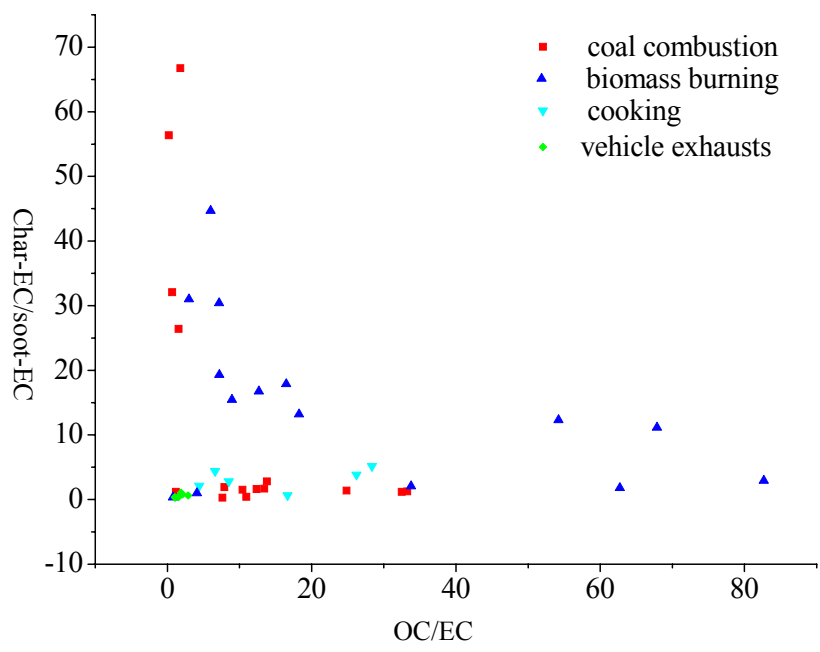

Fig. 6. Picture of the primary emissions of OC/EC ratios and charEC/soot-EC ratios from different sources. Yuan Liu in the Department of Environmental Science and Engineering, Beijing University of China provides some unpublished data, with sampling following Liu et al. (2007). Motor vehicle samples are from Cao et al. (2006) and Chow et al (2004a) using a ground-based sourcedominated sampling method; meat cooking samples from Chow et al (2004a) using an exhaust dilution method; coal samples from Chen et al. (2007), Chow et al. (2004a) and Liu (2007) using an exhaust dilution method and from Cao et al. (2005) using a ground-based source-dominated sampling method; biomass burning samples from Chow et al. (2004a) and Cao et al. (2005) using a ground-based source-dominated sampling method and from Chen et al. (2007) and Liu et al. (2007) using an exhaust dilution method.

increasing slopes and correlations from winter to summer, consistent with the increasing contribution of soot-EC to total EC with the enhanced percentage of motor vehicle emissions in summer.

\subsection{Char-EC/soot-EC ratio as an indicator for source identification}

\subsubsection{Char-EC/soot-EC ratios from primary emissions}

Primary emissions of OC/EC and char-EC/soot-EC ratios from biomass burning, coal combustion, vehicle exhaust, and cooking are presented in Fig. 6. Since there are few reports of char-EC and soot-EC from primary emissions, OC/EC and char-EC/soot-EC ratios in Fig. 6 are calculated using the raw data reported from the eight carbon fractions in the literature measured with the TOR method (Chow et al., 2004a; Cao et al., 2005, 2006; Chen et al., 2007; and some unpublished data from Yuan Liu). Details for the combustion conditions can be found in these articles. Motor vehicle emissions have the lowest OC/EC and char-EC/soot-EC ratios, with char-EC/soot-EC generally lower than 1.0. Coal combustion and biomass burning have higher, albeit distinct, OC/EC and char-EC/soot-EC ratios, which may be controlled mainly

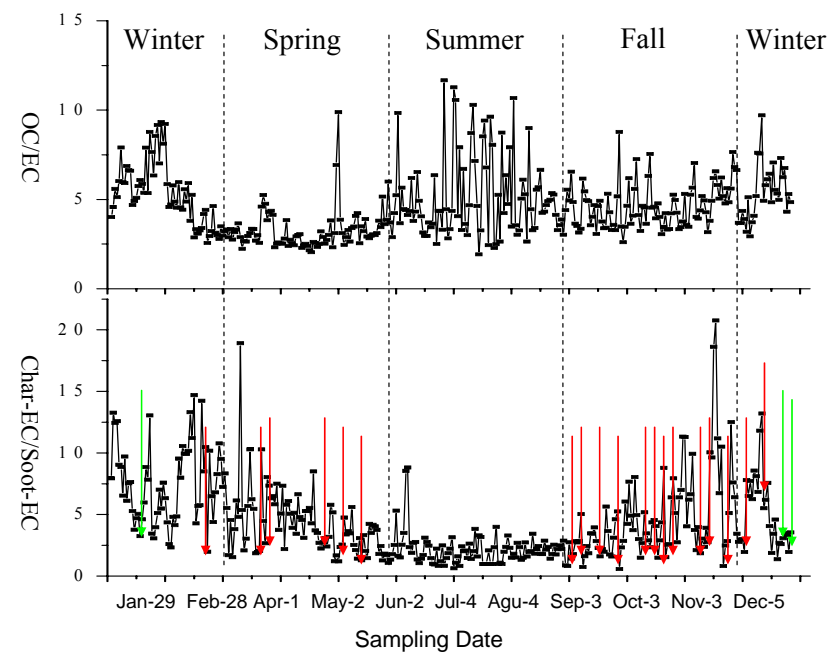

Fig. 7. Temporal variations of $\mathrm{OC} / \mathrm{EC}$ and char-EC/soot-EC, as well as the relation between char-EC/soot-EC and rain and snow in 2004. Red and green arrows represent rain and snow days, respectively, and the arrow locations correspond to the char-EC/soot-EC ratio. Note that not all the rainy and snow days are present, with some continuous days are showed with one arrow. Rainy days in summer are not presented since there are only small variations of char-EC/soot-EC between rainy and non-rainy days.

by the fuel types, combustion mode and temperature, and moisture content, etc. The ratios depend on the mixing function of the different factors. For example, grass combustion may produce lower char-EC/soot-EC, while wood combustion has higher char-EC/soot-EC (Chow et al., 2004a; Chen et al., 2007). Generally, biomass burning by smoldering at low temperatures results in high char-EC/soot-EC (Chen et al., 2007). In coal combustion, bituminous coal generally produces very high char-EC/soot-EC, while anthracite coal produces relatively lower char-EC/soot-EC. Residential coal combustion in $\mathrm{Xi}$ ' an has char-EC/soot-EC ranging from 1.5 to 3.0 (Cao et al., 2005). Residential cooking produces charEC/soot-EC generally within the range of 2.0 to 6.0 (Chow et al., 2004a).

\subsubsection{Source identification from char-EC/soot-EC ratios in Xi'an}

Daily variations in OC/EC and char-EC/soot-EC ratios are presented in Fig. 7. The average OC/EC ratios in winter and summer have almost similar values, and the lowest ratios occurred in spring (Table 1). Monthly variations in OC/EC ratios revealed two peaks, in January and July, respectively (Fig. 3). The first peak can be ascribed to the coal consumption in winter, although SOA formation may also have an important impact (Cao et al., 2005). The next peak is most likely to be linked to SOA formation since motor vehicle exhaust are the main contributor to EC in summer, which have very low primary OC/EC ratios (Fig. 6), 
Table 3. Comparison of different seasonal $\mathrm{PM}_{2.5}$ mass, total carbon (TC), organic carbon (OC), elemental carbon (EC), char-EC, and sootEC concentrations, as well as OC/EC, char-EC/soot-EC between rainy and non-rainy periods. Any day with rain is classified into rainy period. Snow days are also included into rainy period.

\begin{tabular}{|c|c|c|c|c|c|c|c|c|c|c|}
\hline Seasons & Condition & $\begin{array}{l}\text { Mass } \\
\mu \mathrm{g} \mathrm{m}^{-3}\end{array}$ & $\begin{array}{l}\mathrm{TC} \\
\mu \mathrm{g} \mathrm{m}^{-3}\end{array}$ & $\begin{array}{l}\mathrm{OC} \\
\mu \mathrm{g} \mathrm{m}^{-3}\end{array}$ & $\begin{array}{l}\mathrm{EC} \\
\mu \mathrm{g} \mathrm{m}^{-3}\end{array}$ & OC/EC & $\begin{array}{l}\text { Char-EC } \\
\mu \mathrm{g} \mathrm{m}^{-3}\end{array}$ & $\begin{array}{l}\text { Soot-EC } \\
\mu \mathrm{g} \mathrm{m}^{-3}\end{array}$ & $\begin{array}{l}\text { Char-EC/ } \\
\text { Soot-EC }\end{array}$ & $N^{\mathrm{b}}$ \\
\hline \multirow[t]{2}{*}{ Winter } & Non-rain & 240.08 & 79.60 & 66.49 & 13.11 & 5.28 & 11.47 & 1.64 & 7.21 & 77 \\
\hline & Ratio $^{\mathrm{a}}$ & 1.16 & 1.93 & 1.89 & 2.18 & 0.92 & 2.46 & 1.23 & 2.01 & \\
\hline \multirow[t]{2}{*}{ Spring } & Non-rain & 158.63 & 39.87 & 30.04 & 9.84 & 3.18 & 7.95 & 1.88 & 4.36 & 78 \\
\hline & Rain & 95.88 & 22.11 & 16.83 & 5.28 & 4.08 & 3.73 & 1.55 & 2.29 & 9 \\
\hline \multirow[t]{3}{*}{ Summer } & Non-rain & 106.63 & 20.35 & 16.42 & 3.93 & 5.01 & 2.75 & 1.18 & 2.24 & 71 \\
\hline & Rain & 101.00 & 16.52 & 13.65 & 2.87 & 5.58 & 1.83 & 1.03 & 1.90 & 18 \\
\hline & Ratio & 1.06 & 1.23 & 1.20 & 1.37 & 0.90 & 1.50 & 1.14 & 1.18 & \\
\hline \multirow[t]{3}{*}{ Fall } & Non-rain & 190.36 & 52.14 & 42.72 & 9.42 & 4.48 & 7.80 & 1.62 & 5.27 & 67 \\
\hline & Rain & 145.69 & 30.82 & 25.55 & 5.28 & 5.08 & 3.83 & 1.45 & 2.54 & 21 \\
\hline & Ratio & 1.31 & 1.69 & 1.67 & 1.78 & 0.88 & 2.04 & 1.12 & 2.08 & \\
\hline
\end{tabular}

${ }^{a}$ Ratio is that of non-rain to rain data; ${ }^{b} N$ is sample number.

and the higher temperature in summer would produce more SOA (e.g. Turpin and Huntzicker, 1991). This confirms that $\mathrm{OC} / \mathrm{EC}$ ratio is not universally suitable for primary source identification of carbonaceous aerosols, since it is not only influenced by the fuel used (the primary emissions), but also by the formation of SOA.

Unlike OC/EC, char-EC/soot-EC ratios showed a clear seasonal variation, with the highest value of 6.7 in winter and the lowest value of 2.2 in summer. Xi' an has a longterm "heating season" from 15 October to 15 March (Cao et al., 2005). It was reported (Xi' an Clean Energy Office, 2002) that $3.5 \mathrm{Tg}$ coal was consumed as the main energy source in the total primary energy consumption in 2000 , which accounts for $81 \%$ of the total energy consumption. The high char-EC/soot-EC ratios in winter can be attributed to coal consumption for heating. The 2004 coal consumption (http://air.ipe.org.cn/qyInfo.do and references therein) showed $0.9 \mathrm{Tg}$ from residential coal consumption, which was mainly consumed in winter. The average char-EC/soot-EC ratio in summer was still higher than that from road dusts (1.7) in Xi' an city (Han et al., 2009b), which may suggest that apart from the main contributions from motor vehicle exhaust, industrial coal combustion and some biomass burning events in summer cannot be neglected. For example, the biomass burning occurred during 8 and 9 June in rural area around Xi' an caused a sharp increase in char-EC/sootEC ratio, with values close to 10.0 (Fig. 6). Monthly charEC/soot-EC ratios showed their highest peak in February (Fig. 3), with a small decreasing trend in January and December, probably due to the difference in wet scavenging rates by snow and rain between char and soot particles (see Sect. 4.4). The variations in char-EC/soot-EC ratio are con- sistent with the energy sources and thus are an effective indicator for source identification. Since char-EC/soot-EC is well correlated with char-EC concentrations (Table 2), charEC variation may be roughly used for source identification of carbonaceous aerosols.

\subsection{Wet scavenging influencing the discrepancy in char and soot removal}

Generally, carbon concentrations in urban areas are mainly determined by the amounts of fuel consumption. TC, OC and EC, as well as char-EC (Figs. 2 and 3), showed high concentrations in winter and low concentrations in summer, which is in good agreement with fuel consumption in Xi' an, and may be, in part, associated with the different seasonal usage of fuel consumption. Furthermore, temperature may influence carbon, especially OC concentrations, through the formation of SOA (Turpin and Huntzicker, 1991; Cabada et al., 2004) and the partitioning of semi-volatile material (Lipsky and Robinson, 2006; Robinson et al., 2007). In addition, temperature varies with mixing height in $\mathrm{Xi}$ ' an, which would also influence carbon concentrations. Low temperatures would lead to a lower mixing height, reducing particulate dispersion and thus enhancing local pollutant levels.

Rain and snow are important factors influencing atmospheric aerosol concentrations due to their scavenging potential (e.g. Armails, 1999; Jaffe et al., 2005; Meng et al., 2007). Generally, high precipitation occurs in summer and lower precipitation in spring and winter in northern China, including Xi' an, due to the influence of the East Asian monsoon system (Han et al., 2009c). Although the lowest precipitation occurs in spring in Xi' an, the highest concentrations 
of mass, TC, OC, EC, and char-EC occurred in winter, but not in spring, which may suggest that, for these components, the influence of fuel consumption is more important than wet scavenging. Soot-EC concentrations showed coupling with the wet precipitation, with the highest in spring (March and April), and the lowest in summer (Figs. 2, 3, and 7). This pattern suggests that wet precipitation is an important factor influencing soot distribution.

The comparison of seasonal variations between rainy and non-rainy period (Table 3 ) indicates that rain removal is more effective in dry season (winter and spring) than in wet season (summer and fall). This finding is similar to that of Armails (1999), who found that the wet deposition of EC was double during the dry season than during the wet season. Generally, in winter the high pressure associated with the invasion of cold air prevents the air mass diffusion, so that precipitation is the main route for EC removal. In summer, the low pressure and higher mixing height facilitates EC diffusion and thus rain precipitation would be a relatively less effective factor influencing pollutant removal. The char-EC/sootEC ratio variations were also affected by wet precipitation, and showed a great decrease in rainy periods (Table 3 ). This suggests that char and soot have different removal rates by wet scavenging, which may be mainly associated with the difference in char and soot particle sizes. In general, char is composed of large particles $(1-100 \mu \mathrm{m})$ produced from incomplete combustion at low temperatures, and would be expected to be easily been removed by wet deposition. Soot, composed of submicron particles, can remain suspended for time scales of the order of a month (Ogren and Charlson, 1983), and thus is more difficult to remove.

\section{Conclusion}

This study demonstrates that char and soot have different distribution characteristics in the atmosphere. Similar to previous reported TC, OC and total EC, char-EC showed high seasonal variations, with the maximum concentrations in winter $\left(10.49 \pm 5.95 \mu \mathrm{g} \mathrm{m}^{-3}\right)$ being $\sim 4$ times of that in summer $\left(2.57 \pm 1.82 \mu \mathrm{g} \mathrm{m}^{-3}\right)$. This is associated with $\mathrm{Xi}^{\prime}$ an winter heating. However, soot-EC revealed only small variations in different seasons, and this variation is probably in part due to the wet scavenging. Strong correlations between EC and char-EC suggest that char-EC concentrations can be calculated from previously reported EC concentrations. However, previously reported total EC in the literature reflected the distribution characteristics of char only, while soot's distribution characteristics may be overlooked. Soot-EC can be seen as a background fraction, contributing to $18.4 \%$ of Xi' an total $\mathrm{EC}$ on average, and had a background value of $\sim 1.15 \mu \mathrm{g} \mathrm{m}^{-3}$ in $\mathrm{PM}_{2.5}$, which may be mainly associated with the motor vehicle emission throughout the year. Previous studies suggested that soot is strong light absorbing with little spectral dependence; while char tends to absorb strongly in the UV spectrum. Thus, efforts to reduce motor vehicle emissions are very important for the mitigation of the present warming trends. Char-EC/soot-EC ratio is an effective indicator of source identification for carbonaceous aerosols. However, wet scavenging is also an important factor influencing the char-EC/soot-EC ratio because of the difference in removal rate of char and soot. Since a limited amount of data is now available concerning source emissions of OC/EC and char$\mathrm{EC} /$ soot-EC ratios, more studies in different source emissions are needed in the future. In addition, such studies may help to establish the relationship between primary OC/EC and char-EC/soot-EC ratios, providing new insights on methods for SOA calculation.

Acknowledgements. This study is supported by the Knowledge Innovation Program of the Chinese Academy of Sciences (KZCX2-YW-QN113, kzcx2-yw-148), the National Natural Science Foundation of China (NSFC40925009, 40675081, 40599420), the National Basic Research Program of China (2010CB833403, 2004CB720203), and the State Key Laboratory of Loess \& Quaternary Geology (SKLLQG0718 and LQ0701).

Edited by: T. Kirchstetter

\section{References}

Armails, S.: Wet deposition of elemental carbon in Lithuania, Sci. Total Environ., 239, 89-93, 1999.

Andreae, O. M., and Gelencsér, A.: Black carbon or brown carbon? The nature of light-absorbing carbonaceous aerosols, Atmos. Chem. Phys., 6, 3131-3148, 2006, http://www.atmos-chem-phys.net/6/3131/2006/.

Avakian, M. D., Dellinger, B., Fiedler, H., Gullet, B., Koshland, C., Marklund, S., Oberdorster, G., Safe, S., Sarofim, A., Smith, K. R., Schwartz, D., and Suk, W. A.: The origin, fate, and health effects of combustion by-products: a research framework, Environ. Health Perspect., 110, 1155-1162, 2002.

Birch, M. E.: Analysis of carbonaceous aerosols: Interlaboratory comparison, Analyst, 123, 851-857, 1998.

Bond, T. C.: Spectral dependence of visible light absorption by carbonaceous particles emitted from coal combustion, Geophys. Res. Lett., 28, 4075-4078, 2001.

Bond, T. C., Covert, D. S., Kramlich, J. C., Larson, T. V., and Charlson, R. J.: Primary particle emissions from residential coal burning: Optical properties and size distributions, J. Geophys. Res., 107(D21), 8347, doi:10.1029/2001JD000571, 2002.

Bond, T. C., Streets, D. G., Yarber, K. F., Nelson, S. M., Woo, J.-H., and Klimont, Z.:, A technology based inventory of black and organic carbon emissions from combustion, J Geophys. Res., 108(D21), 8823, doi:10.1029/2002JD003117, 2004.

Cabada, J. C., Pandis, S. N., Subramanian, R., Robinson, A.L., Polidori, A., and Turpin, B.: Estimating the secondary organic aerosol contribution to $\mathrm{PM}_{2.5}$ using the EC tracer method. Aerosol Sci. Technol., 38, 140-155, 2004.

Cachier, H., Liousse, C., Pertuisol, M. H., Gaudichet, A., Echalar, F., and Lacaux, J. P.: African fine particulate emissions and atmospheric influence, in: Biomass Burning and Global Change, 
edited by: Levine, E. J. S., MIT Press, London, UK, 428-440, 1996.

Cao, J. J., Lee, S. C., Ho, K. F., Zhang, X. Y., Zou, S. C., Fung, K. K., Chow, J. C., and Watson, J. G.: Characteristics of carbonaceous aerosol in Pearl River Delta region, China during 2001 winter period, Atmos. Environ., 37, 1451-1460, 2003.

Cao, J. J., Wu, F., Chow, J. C., Lee, S. C., Li, Y., Chen, S. W., An, Z. S., Fung, K., Watson, J. G., Zhu, C. S., and Liu, S. X.: Characterization and source apportionment of atmospheric organic and elemental carbon during fall and winter of 2003 in Xi' an, China, Atmos. Chem. Phys., 5, 3127-3137, 2005, http://www.atmos-chem-phys.net/5/3127/2005/.

Cao, J. J., Lee, S. C., Ho, K. F., Fung, K., Chow, J. C., and Watson, J. G.: Characterization of Roadside Fine Particulate Carbon and its Eight Fractions in Hong Kong, Aero. Air Quality Res., 6, 106122, 2006.

Cao, J. J., Lee, S. C., Chow, J. C., Watson, J .G., Ho, K. F., Zhang, R. J., Jin, Z. D., Shen, Z. X., Chen, G. C., Kang, Y. M., Zou, S. C., Zhang, L. Z., Qi, S. H., Dai, M. H., Cheng, Y., and $\mathrm{Hu}, \mathrm{K}$.: Spatial and seasonal distributions of carbonaceous aerosols over China, J. Geophys. Res., 112, D22S11, doi:10.1029/2006JD008205, 2007.

Castro, L. M., Pio, C. A., Harrison, R. M., and Smith, D. J. T.: Carbonaceous aerosol in urban and rural European atmospheres: estimation of secondary organic carbon concentrations, Atmos. Environ., 33, 2771-2781, 1999.

Chen, L.-W. A., Moosmuller, H., Arnott, W. P., Chow, J. C., Watson, J. G., Susott, R. A., Babbitt, R. E., Wold, C. E., Lincoln, E. N., and Hao, W. M.: Emissions from laboratory combustion of wildland fuels: Emission factors and source profiles. Environ. Sci. Technol., 41, 4317-4325, 2007.

Cheng, Y., He, K. B., Duan, F. K., Zheng, M., Ma, Y. L., and Tan, J. H.: Positive sampling artifact of carbonaceous aerosols and its influence on the thermal-optical split of OC/EC. Atmos. Chem. Phys. Phys., 9, 7243-7256, 2009.

Chow, J. C., Watson, J. G., Pritchett, L. C., Pierson, W. R., Frazier, C. A., and Purcell, R. G.: The DRI thermal/optical reflectance carbon analysis system: description, evaluation and applications in U.S. air quality studies, Atmos. Environ., 27, 1185-1201, 1993.

Chow, J. C., Watson, J. G., Crow, D., Lowenthal, D. H., Merrifield, T.: Comparison of IMPROVE and NIOSH carbon measurements, Aerosol Sci. Tech., 34, 23-34, 2001.

Chow, J. C., Watson, J. G., Kuhns, H. D., Etyemezian, V., Lowenthal, D. H., Crow, D. J., Kohl, S. D., Engelbrecht, J. P., and Green, M.C.: Source profiles for industrial, mobile, and area sources in the Big Bend Regional Aerosol Visibility and Observational (BRAVO) Study, Chemosphere, 54, 185-208, 2004a.

Chow, J. C., Watson, J. G., Chen, L. A., Arnott, W. P., and Moosmuller, H.: Equivalence of elemental carbon by thermal/optical reflectance and transmittance with different temperature protocols, Environ. Sci. Tech., 38, 4414-4422, 2004b.

Duan, J., Tan, T., Cheng, D., Bi, X., Deng, W., Sheng, G., Fu, J., and Wong, M. H.: Sources and characteristics of carbonaceous aerosol in two largest cities in Pearl River Delta Region, China, Atmos. Environ., 41, 2895-2903, 2007.

Elmquist, M., Cornelissen, G., Kukulska, Z., and Gustafsson, O.: Distinct oxidative stabilities of char versus soot black carbon: Implications for quantification and environmen- tal recalcitrance, Global Biogeochem. Cycles, 20, GB2009, doi:10.1029/2005GB002629, 2006.

Gelencsér, A.: Major Carbonaceous particle types and their sources, In: Carbonaceous Aerosol. Springer, The Netherlands, 45-148, 2004.

Goldberg, E. D.: Black carbon in the environment, John Wiley \& Sons, Inc., New York, USA, 1-42, 1985.

Gustafsson, Ö., Krusa, M., Zencak, Z., Sheesley, R. J., Granat, L., Engstrom, E., Praveen, P. S., Rao, P. S. P., Leck, C., and Rodhe, H.: Brown clouds over south Asia: Biomass or fossil fuel combustion?, Science, 323, 495-498, 2009.

Hammes, K., Schmidt, M. W. I., Smernik, R. J., Currie, L. A., Ball, W. P., Nguyen, T. H., Louchouarn, P., Houel, S., Gustafsson, Ö., Elmquist, M., Cornelissen, G., Skjemstad, J. O., Masiello, C. A., Song, J., Peng, P., Mitra, S., Dunn, J. C., Hatcher, P. G., Hockaday, W. C., Smith, D. M., Hartkopf-Fröder, C., Böhmer, A., Lüer, B., Huebert, B. J., Amelung, W., Brodowski, S., Huang, L., Zhang, W., Gschwend, P. M., Flores-Cervantes, D. X., Largeau, C., Rouzaud, J., Rumpel, C., Guggenberger, G., Kaiser, K., Rodionov, A., Gonzalez-Vila, F. J., Gonzalez-Perez, J. A., de la Rosa, J. M., Manning, D. A. C., López-Capél, E., and Ding, L.:, Comparison of quantification methods to measure fire-derived (black/elemental) carbon in soils and sediments using reference materials from soil, water, sediment and the atmosphere, Global Biogeochem. Cy., 21, GB3016, doi:10.1029/2006GB002914, 2007.

Han, Y. M.: Historical variation of atmospheric black carbon and fire events recorded by lake sediments in Daihai and Taihu regions in the last 500 years, Ph.D Thesis, (in Chinese with English abstract), Chinese Academy of Sciences, 2006.

Han, Y. M., Cao, J. J., Chow, J. C., Watson, J. G., Fung, K., Jin, Z. D., Liu, S. X., and An, Z. S.: Evaluation of the thermal/optical reflectance method for discrimination between soot- and charEC, Chemosphere, 69, 569-574, 2007a.

Han, Y. M., Cao, J. J., An, Z. S., Chow, J. C., Waston, J. G., Jin, Z. D., Fung, K., and Liu, S. X.: Evaluation of the thermal/optical reflectance method for quantification of elemental carbon in sediments, Chemosphere, 69, 526-533, 2007b.

Han, Y. M., Han, Z. W., Cao, J. J., Chow, J. C., Watson, J. G., An, Z. S., Liu, S. X., and Zhang R. J.: Distribution and origin of carbonaceous aerosol over a rural high-mountain lake area, Northern China and its transport significance, Atmos. Environ., 42, 2405-2414, 2008.

Han, Y. M., Cao, J. J., Posmentier, E. S., Chow, J. C., Watson, J. G., Fung, K., Jin, Z. D., Liu, S. X., and An, Z. S.: The effect of acidification on the determination of elemental carbon, char-, and soot-elemental carbon in soils and sediments, Chemosphere, 75, 92-99, 2009a.

Han, Y. M., Cao, J. J., Chow, J. C., Watson, J. G., An, Z. S., and Liu, S. X.: Elemental carbon in urban soils and road dusts in Xi'an, China and its implication for air pollution, Atmos. Environ., 43, 2464-2470, 2009b.

Han, Y. M., Cao, J. J., Jin, Z. D., and An, Z. S.: Elemental composition of aerosols in Daihai, a rural area in the front boundary of the summer Asian monsoon, Atmos. Res., 92, 229-235, 2009c.

Han, Y. M., Lee, S. C., Cao, J. J., Ho, K. F., and An, Z. S.: Spatial distribution and seasonal variation of char-EC and soot-EC in the atmosphere over China, Atmos. Environ., 43, 6066-6073, 2009d.

Hansen, J. and Nazarenko, L.: Soot climate forcing via snow and 
ice albedos, Proc. Natl. Acad. Sci., 101, 423-428, 2004.

He, K., Yang, F., Ma, Y., Zhang, Q., Yao, X., Chan, C. K., Cadle, S., Chan, T., and Mulawa, P.: The characteristics of $\mathrm{PM}_{2.5}$ in Beijing, China, Atmos. Environ., 35, 4959-4970, 2001.

Jacobson, M. Z.: Strong radiative heating due to the mixing state of black carbon in atmospheric aerosols, Nature, 409, 695-697, 2001.

Jaffe, D., Tamura, S., and Harris, J.: Seasonal cycle and composition of background fine particles along the west coast of the US, Atmos. Environ., 39, 297-306, 2005.

Jones, T. P., Chaloner, W. G., and Kuhlbusch, T. S. J.: Proposed biogeological and chemical based terminology for fire-altered plant matter, in: Sediment Records of Biomass Burning and Global Change, edited by: Clark, J. S., Cachier, H., Goldammer, J. G., Stocks, B., NATO ASI Series 1: Global Environmental Change, Springer Verlag, Berlin, 51, 9-22, 1997.

Kirchstetter, T. W., Corrigan, C. E., and Novakov, T.: Laboratory and field investigation of the adsorption of gaseous organic compounds onto quartz filters, Atmos. Environ., 35(9), 1663-1671, 2001.

Kirchstetter, T. W., Novakov, T., and Hobbs, P. V.: Evidence that the spectral dependence of light absorption by aerosols is affected by organic carbon, J. Geophys. Res., 109, D21208, doi:10.1029/2004JD004999, 2004.

Kirchstetter, T. W., Novakov, T., Hobbs, P. V., and Magi, B.: Airborne measurements of carbonaceous aerosols in southern Africa during the dry biomass burning season, J. Geophy. Res., 108(D13), 8476, doi:10.1029/2002JD002171, 2003.

Koelmans, A. A., Jonker, M. T. O., Cornelissen, G., Bucheli, T. D., van Noort, P. C. M., and Gustafsson, O.: Black carbon: The reverse of its dark side, Chemosphere, 63, 365-377, 2006.

Kuhlbusch, T. A. J.: Black carbon in soils, sediments, and ice cores, in: Environmental analysis and remediation, edited by: Meyers, R. A., John Wiley \& Sons, Toronto, Canada, 813-823, 1997.

Lewis, K., Arnott, W. P., Moosmuller, H., and Wold, C. E.: Strong spectral variation of biomass smoke light absorption and single scattering albedo observed with a novel dual-wavelength photoacoustic instrument, J. Geophys. Res., 113, D16203, doi:10.1029/2007JD009699, 2008.

Lim, B. and Cachier, H.: Determination of black carbon by chemical oxidation and thermal treatment in recent marine and lake sediments and Cretaceous-Tertiary clays, Chem. Geol., 131, 143-154, 1996.

Lipsky, E. M., and Robinson, A. L.: Effects of dilution on fine particle mass and partitioning of semi-volatile organics in diesel exhaust and wood smoke, Environ. Sci. Technol., 40(1), 155-162, 2006.

Liu, Y., Zhang, Y. X., Wei, Y. J., Dou, H., Gu, D. S., Zen, L. M., and Shao, M.: Measurement of emission factors of carbonaceous aerosols from residential coal combustion, ACTA Scientiae Circumstantiae, (in Chinese with English abstract), 27, 1409-1416, 2007.

Malm, W. C., Schichtel, B. A., Pitchford, M. L., Ashbaugh, L. L., and Eldred, R. A.: Spatial and monthly trends in speciated fine particle concentration in the United States, J. Geophys. Res., 109, D03306, doi:-10.1029/2003JD003739, 2004.

Masiello, C. A.: New directions in black carbon organic geochemistry, Mar. Chem., 92, 201-213, 2004.

Meng, Z. Y., Jiang, X. M., Yan, P., Lin, W. L., Zhang, H. D., and
Wang, Y.: Characteristics and sources of $\mathrm{PM}_{2.5}$ and carbonaceous species during winter in Taiyuan, China, Atmos. Environ., 41, 6901-6908, 2007.

Menon, S., Hansen, J., Nazarenko, L., and Luo, Y. F.: Climate effects of black carbon aerosols in China and India, Science, 297, 2250-2253, 2002.

NIOSH: Method 5040 Issue 3 (Interim): Elemental Carbon (Diesel Exhaust). in: NIOSH Manual of Analytical Methods, National Institute of Occupational Safety and Health, Cincinnati, OH, USA, 1999.

Nguyen, T. H., Brown, R. A., and Ball, W. P.: An evaluation of thermal resistance as a measure of black carbon content in diesel soot, wood char, and sediment, Org. Geochem., 35, 217-234, 2004.

Novakov, T.: Soot in the atmosphere, in: Particulate Carbon: Atmospheric Life Cycle, edited by: Wolff, G. T. and Klimisch, R. L., Plenum Press, New York, USA, 1982.

Novakov, T. and Corrigan, C. E.: Thermal characterization of biomass smoke particles, Mikrochimica Acta, 119, 157-166, 1995.

Ogren, J. A. and Charlson, R. J.: Elemental carbon in the atmosphere: Cycle and lifetime, Tellus, 35B, 241-154, 1983.

Olson, D. A., and Norris, G. A.: Sampling artifacts in measurement of elemental and organic carbon: Low-volume sampling in indoor and outdoor environments, Atmos. Environ., 39, 54375445, 2005.

Pöschl, U.: Atmospheric aerosols: Composition, transformation, climate and health effects, Angew. Chem. Int. Ed., 44, 75207540, 2005.

Reid, J. S., Eck, T. F., Christopher, S. A., Koppmann, R., Dubovik, O., Eleuterio, D. P., Holben, B. N., Reid, E. A., and Zhang, J.: A review of biomass burning emissions part III: intensive optical properties of biomass burning particles, Atmos. Chem. Phys., 5, 827-849, 2005, http://www.atmos-chem-phys.net/5/827/2005/.

Robinson, A. L., Donahue, N. M., Shrivastava, M. K., Weitkamp, E. A., Sage, A. M., Grieshop, A. P., Lane, T. E., Pierce, J. R., and Pandis, S. N.: Rethinking organic aerosols: Semivolatile emissions and photochemical aging, Science, 315, 1259-1262, 2007.

Schauer, J. J., Mader, B. T., Deminter, J. T., Heidemann, G., Bae, M. S., Seinfeld, J. H., Flagan, L. C., Cary, R. A., Smith, D., Hueburt, B. J., Bertram, T., Howell, S., Kline, J. T., Quinn, P., Bates, T., Turpin, B., Lim, H. J., Yu, J. Z., Yang, H., and Keywood, M. D. : ACE-Asia intercomparison of a thermal-optical method for the determination of particle-phase organic and elemental carbon, Environ. Sci. Technol., 37, 993-1001, 2003.

Schichtel, B. A., Malm, W. C., Bench, G., Fallon, S., McDade, C. E., Chow, J. C., and Watson, J. G.: Fossil and contemporary fine particulate carbon fractions at 12 rural and urban sites in the United States, J. Geophys. Res., 113, D02311, doi:10.1029/2007JD008605, 2008.

Schmidt, M. W. I., Skjemstad, J. O., Czimczik, C. I., Glaser, B., Prentice, K. M., Gelinas, Y., and Kuhlbusch, T. A. J.: Comparative analysis of black carbon in soils, Global Biogeochem. Cy., 15, 163-167, 2001.

Schnaiter, M., Horvath, H., Mohler, O., Naumann, K.-H., Saatoff, H., Schock, O. W.: UV-VIS-NIR spectral optical properties of soot and soot-containing aerosols, J. Aerosol Sci., 34, 14211444, 2003.

Shindell, D. and Faluvegi, G.: Climate response to regional radia- 
tive forcing during the twentieth century, Nature Geosci., 2, 294 300, 2009.

Subramanian, R., Khlystov, A. Y., Cabada, J. C., and Robinson, A. L.: Positive and negative artifacts in particulate organic carbon measurements with denuded and undenuded sampler configurations, Aerosol Sci. Tech., 38(S1), 27-48, 2004.

Subramanian, R., Khlystov, A. Y., and Robinson, A. L.: Effect of peak inert-mode temperature on elemental carbon measured using thermal-optical analysis, Aerosol Sci. Tech., 40, 763-780, 2006.

Turpin, B. J. and Huntzicker, J. J.: Secondary formation of organic aerosol in the Los Angeles Basin: a descriptive analysis of organic and elemental carbon concentrations, Atmos. Environ., 25A, 207-215, 1991.

Turpin, B. J., Saxena, P., and Andrews, E.: Measuring and simulating particulate organics in the atmosphere: Problems and prospects, Atmos. Environ., 34(18), 2983-3013, 2000.

Yang, H. and Yu, J. Z.: Uncertainties in charring correction in the analysis of elemental and organic carbon in atmospheric particles by thermal/optical methods, Environ. Sci. Technol., 36, 51995204, 2002.
Ye, B., Ji, X., Yang, H., Yao, X., Chan, C. K., Cadle, S. H., Chan, T., and Mulawa, P. A.: Concentration and chemical composition of $\mathrm{PM}_{2.5}$ in Shanghai for a 1-year period, Atmos. Environ., 37, 499-510, 2003.

Yu, J. Z., Xu, J. H., and Yang, H.: Charring characteristics of atmospheric organic particulate matter in thermal analysis, Environ. Sci. Technol., 36, 754-761, 2002.

Yu, J. Z., Tung, J. W. T., Wu, A. W. M., Lau, A. K. H., Louie, P. K.K., and Fung, J. C. H.: Abundance and seasonal characteristics of elemental and organic carbon in Hong Kong $\mathrm{PM}_{10}$, Atmos. Environ., 38, 1511-1521, 2004.

Yung, Y. L., Shia, C., and Herman. H. L.: Is the biomass burning source of CO decreasing? Chemosphere: Global Change Science, 1, 83-90, 1999.

Zhang, R. J., Cao, J. J., Lee, S. C., Shen, Z. X., and Ho, K. F.: Carbonaceous aerosols in $\mathrm{PM}_{10}$ and pollution gases in winter in Beijing, J. Environ. Sci., 19, 564-571, 2007. 